\title{
APPLYING PRESIDENT HO CHI MINH'S WORKING STYLE IN BUILDING FEMALE LEADERS AT ALL LEVELS AND SECTORS IN THE CURRENT SITUATION
}

\author{
Anh Thi Que Nguyen ${ }^{1,+}$, \\ Hoa Ngoc Dinh ${ }^{2}$
}

\author{
Article History \\ Received: July 15, 2019 \\ Accepted: August 15, 2019 \\ Published: September 30, 2019 \\ Keywords \\ Applying, creation, Ho Chi \\ Minh's working style, female \\ leader
}

\author{
${ }^{1}$ Academy of Politics Region I, Ho Chi Minh National Academy of Politics, \\ Vietnam; ${ }^{2}$ People's Public Security Political Academy, Vietnam \\ ${ }^{+}$Corresponding author $\bullet$ Email: nguyenqueanh1969@gmail.com
}

\section{INTRODUCTION}

Female leaders at all levels and sectors in Vietnam are now striving to contribute their strength and intelligence to the country's renovation and development in many aspects. They are self-awared, self-educated, self-trained, selfimproved in order to build a working and leadership style that satisfies society's demands in the innovation, exchange, and sustainable development of the country. Female leaders today define the working style and leadership as the ways to perform consistently at work, study, and life to aim at the values of truth - kindness - beauty, improving their living quality. They understand the style is formed on the basis of ideology, morality, lifestyle, talent, forte, temperament, etc. They choose a democratic, public, scientific, exemplary style in line with the leadership of President Ho Chi Minh, which is a valuable lesson, a guideline to guide his way of living, studying, working and contributing to the nation. In the narrow framework of the article, the author only presents the content of the working style and leadership of President Ho Chi Minh and the application to build a contingent of female leaders at all levels and sectors of our country in current stage to meet all requirements of reform, global integration for the sustainable development of the nation.

\section{LITERATURE REVIEW}

In the reform period, the policy of Party and Government of Vietnam on the work of women and gender equality is reflected throughout Resolutions of Party Congress, resolutions and directives of the Party Central Committee, the Politburo, and Secretariat on public affairs, advocacy of female official and women. The State has issued many specific policies to create conditions for women to develop and promote gender equality.

The Politburo's Resolution No. 11-NQ/TW dated April 27, 2007 on the Work of Women during the period of increasing industrialization and modernization of the country (Politburo, 2007) stated the Party's views on the work of women: "Promoting women's role and great potential in the cause of industrialization, modernization, national construction and defense, women's empowerment, gender equality in all fields of politics and economy, culture, and society is one of the important revolutionary tasks and objectives for Vietnam in the new era." In addition to the Politburo's Resolution No. 11-NQ/TW dated April 27, 2007 on the Work of Women during the period of increasing industrialization and modernization, Vietnam also has Government's Action Plan to 2020 implementing Resolution No. 11-NQ/TW (Government, 2007) and Decision No. 2351/QD-TTg (Prime Minister, 2010) dated December 24, 2010, in which Prime Minister approved the National Strategy on Gender Equality for the 2011-2020 period.

In recent years, human resource construction including female leaders at all levels and sectors in Vietnam, has been paid more attention. "Today's global issues require leaders with so many skills and changes etc. that can only come from a wide range of ideas and participants. Women bring different skills, perspectives, structural and cultural 
differences to deliver effective solutions. Based on female leaders we can make changes and solutions for global solutions" (Gwen K. Young, 2016).

Many studies have pointed out the importance of female leadership from modern theories about political representation: official representation, descriptive representation, symbolic representation and substantive representation. Theories about increasing female representation in leadership and management positions are based on the notion of formal and descriptive representation. Female leaders formally represent the needs, interests and concerns of other women in our society; ensure better quality for laws and public policies; help solve problems in leadership and management. Specifically, female leaders bring new knowledge; identify new issues in policies; create new tools to identify important policy issues. Theories on increasing the number of female leaders on leading and managing positions are based on the concept of substantive representation, for the sake of the represented. Specifically, female leaders prioritize the development of education, health care, environmental protection and other important components contributing to sustainable development; help develop and improve the quality of women protection policies; participate in maintaining and rebuilding peace effectively. Theories on increasing female representation in formal, managerial positions are based on the concept of symbolic representation. In particular, female leadership in public sectors increases the demand for women's political participation; contribute to changing gender-based cultural stereotypes about women's role; gradually build a culture of social gender equality in our society; increase citizens' belief in Party and State's democracy; strengthen the legitimacy of governing bodies representing the present service society. Theories on increasing female representation in formal, managerial positions are based on economic efficiency. Women's official management represents the effective use of human resources for national development; brings economic benefits to organizations and the nation. Female leaders' presence in managing positions at all levels and sectors is correlated with the profitability at all levels and sectors. Theories about increasing the number of female leaders in official and managerial positions are based on the Party's guidelines, policies and State's laws which contribute to improving Vietnam's gender equality achievements in international charts; contribute to the implementation of Vietnam's tasks and goals in the new period and implement gender equality targets set by Vietnam's Party and State (Hien, L. T., 2018).

In the report "Women's Participation in Leadership and Management in Vietnam", Jean Muro (2012) identifies trends for women's participation in government agencies; describes an overview of the legislative framework related to women's leadership; analyzes challenges and barriers facing women. This author asserted that Vietnam has gained many achievements in getting women's involvement in politics and leadership, but there is gap between the goals and expectations mentioned in Party and State's documents compared to the fact. The report also does not use the systematic explanatory framework to explain barriers and challenges to women in political and leadership positions. Overall, empowering women in general and women's leadership in particular is one of the eight Millennium Development Goals set by the United Nations in 2015 (Diep, D. X., 2012; Hanh C. T., 2012).

Research topics, including the grassroots decentralization project of the Center for Gender and Female Leader Research in 2017, "Enhancing women's participation in leadership and management in public administration sectors in Vietnam (via Son La survey)" (Thi, T. T. M., 2016), also contributes much to the above content. All these are the facilities and conditions for female officials and leaders at all levels to train, build and perfect their own leadership styles, meet the innovation, global integration and sustainable development of Vietnam. They will be meant to instill the desire, hope, needs and confidence for many women and girls to become leaders and managers in the future. They will be an important factor for the development of transparent democracy and service in Vietnam.

\section{RESEARCH METHODS AND RESULTS}

\subsection{Research methods}

- Studying and researching Ho Chi Minh's working style along; studying and researching the learning and practicing Ho Chi Minh's working style for female leaders at all levels and sectors in Vietnam today.

- Referring to scientific research on female leaders and development policies for female leaders at all levels in Vietnam today.

- Finding out and observing the performance of female leaders at all levels and sectors when doing official duties.

Firstly, the author makes qualitative research to generalize, synthesize and affirm that female leaders at all levels in Vietnam have now learned Ho Chi Minh's working style creatively in practising and building a democracy, 
suitable for the mass, scientific working and leadership style to meet the innovation and global integration for the sustainable development of the nation.

By the above steps, the research points out contents that female leaders at all levels have learned in Ho Chi Minh's working style to complete their capacities to meet the innovation, and global integration for the sustainable development of the nation.

The article proposes solutions to build female leaders who meet the principles of President Ho Chi Minh's working style; to create a wide range of influences on studying, applying creatively and successfully for the current leadership style in our country.

\subsection{Research results}

\subsubsection{Applying President Ho Chi Minh's working style to build a team of female workers at all levels and sectors}

President Ho Chi Minh highly appreciated the role of officials. He considers "officials the root of all work" (Central Committee of the Communist Party of Vietnam, 2011). "Officials are the chain of the apparatus" (Central Committee of the Communist Party of Vietnam, 2011) and concludes: "The success or failure of the work is due to good or poor officials" (Central Committee of the Communist Party of Vietnam, 2011). He was interested in building and training officials, party members, leaders and managers of the Party and State, including female leaders at all levels and sectors.

Throughout his life, President Ho Chi Minh left valuable instructions for building officials' working style in general, female leaders at all levels and sectors in particular. Ho Chi Minh's working style is a whole system logically developing from thinking to speaking, writing, and expression through working style, leadership, behavior and daily activities. Learning his style is the guideline for success for each person in the assigned tasks and responsibilities. In a narrow framework, the article only presents the content of the working style and leadership of President Ho Chi Minh and the application to build a team of female leaders at all levels and sectors in Vietnam at the present period. Studying and following Ho Chi Minh's working style in building working style, leading for female leaders at all levels and sectors in the current period should focus on implementing the following contents:

\subsubsection{Democratic style}

President Ho Chi Minh said that the style and way of doing democracy are the leading style that officials need. He pointed out: "The principle of democratic centralism is the basic organizational principle of state agencies in our regime" (Central Committee of the Communist Party of Vietnam, 2011) and "our regime is democracy, thinking must be free" (Central Committee of the Communist Party of Vietnam, 2011). Therefore, female leaders at all levels and sectors must create a democratic atmosphere within the country by sincerely listening to and inspiring others, party members, and lower levels staff to speak out their views and opinions. That way, the staff and the mass will eagerly set out to take the initiative. This is how female officials "learn public initiatives to lead the mass" (Central Committee of the Communist Party of Vietnam, 2011). The initiatives of the mass are recognized, respected, praised, and the more creative people are motivated to work. Female leaders' democratic style at all levels and sectors not only inspires creativity, promotes the spirit of dedication from staff and the mass but also makes organizations and unions more attached.

Female leaders at all levels and sectors having democratic styles are practicing well the principle of "leadership and individuals in charge" (Central Committee of the Communist Party of Vietnam, 2011), which is also a way to promote the wisdom and experience of many people. They must honestly listen to the criticism of their staff and seriously correct themselves with the spirit of learning. In doing so, it is certain that female leaders at all levels and branches will be respected by the mass and staff, especially talented staff who will be willing to contribute ideas and support ideas in real work for common goals.

Democratic style according to Ho Chi Minh's ideology must be oriented with leadership, but not to be overdone or disorganized. One of the basic principles of organization and Party activities is "democratic focus" (Central Committee of the Communist Party of Vietnam, 2011). Talking about the power of democracy, Ho Chi Minh once said: "Democratic practice is a universal key which can solve all difficulties" (Central Committee of the Communist Party of Vietnam, 2011). If female leaders at all levels and sectors do not have democratic style or only speak but do not implement democracy then they are losing their most effective tool to reach goals (Central Committee of the 
Communist Party of Vietnam, 2011). In that case, "no matter how many orders, decisions or circulars they release" (Central Committee of the Communist Party of Vietnam, 2011), works will still not be done.

Democratic style requires female leaders at all levels and sectors to closely follow the mass, paying attention to understanding people's aspirations, taking care of all aspects of their staff's life; believing and respecting people, paying attention to listening to and resolving legitimate proposals of the mass, ready to absorb public criticism and correct their shortcomings.

Closely attached to democratic style is public style. Ho Chi Minh requires officials in general and female leaders at all levels and sectors in particular to have a public style in working, stemming from the principle of the role of the mass: No matter how easy the work is, if there is no support from the mass, it will go nowhere. No matter how hard it is, if the mass support, things will be done. Public style requires female leaders at all levels and sectors to be close to the mass, listen to and understand the desire of the mass. Female leaders at all levels and sectors must regularly go down to their respective establishments.

The public style does not mean "following the mass" (Central Committee of the Communist Party of Vietnam, 2011) because according to Ho Chi Minh, "Among the people, there are many different classes, different levels, different opinions" (Central Committee of the Communist Party of Vietnam, 2011). Female leaders at all levels and sectors have a strong spirit to not only improve the enlightened and intellectual level of the mass, creating a positive change in the awareness of a "slow" and moderate mass population but also well perform their leadership role.

Ho Chi Minh's public style is to know how to organize the movement in accordance with the level and capacity of the mass, not to force subjective opinion on others. Because "if you keep doing what you want, according to your thoughts subjectively, and then tie it to the mass, it is no different to cutting your foot to fit the shoes. Everyone chooses the shoes that fit them. No one cut their foot to fit the shoes" (Central Committee of the Communist Party of Vietnam, 2011). He affirmed that we had to work, organize, talk, propagate, write a newspaper, etc following the mass (Central Committee of the Communist Party of Vietnam, 2011).

The public style of female leaders at all levels and sectors is shown in daily living habits: simple, sociable, not privileged. Ho Chi Minh warned about some deviant thoughts of officials who thought that "to dress up to keep the prestige and keep the face" (Central Committee of the Communist Party of Vietnam, 2011). Female leaders at all levels and sectors who practice the public style will be loved, trusted, supported and the work will soon succeed.

\subsubsection{Scientific style}

The scientific working style requires female leaders at all levels and sectors when considering and making decisions have to investigate, research, analyze comprehensively, respect the decision-making process and take opinions from leaders and the mass in a clear, grand way. President Ho Chi Minh pointed out: "Once having a problem, we have to ask the question: Why does this problem exist? To handle this, what is the result? We have to think carefully. Do not rush, do not harass, do not dose. Do not do what you want" (Central Committee of the Communist Party of Vietnam, 2011). Everything must be investigated clearly and carefully before making decision and implementing it. For new, complex issues that have a great impact on party, organizations, agencies, the public, and citizens, it is necessary to do a pilot before making a decision. No decision should be made if there is not enough sufficient information or no effective plan. We have to avoid being subjective, aiming for short outcomes and running after achievements.

Works must have clear and practical goals and plans. In order to have a scientific plan, female leaders at all levels and sectors must "do the main and important job first, avoid being disorganized and work as they want" (Central Committee of the Communist Party of Vietnam, 2011), avoid outlining the working program too wide but less practical, avoid the disease of "beating the drumstick" (Central Committee of the Communist Party of Vietnam, 2011), causing waste of money, manpower, time of the mass.

The scientific working style is to appreciate the working time and create the best results in the shortest time. Time also needs saving like wealth. For wealth, we can work hard to get but once time has passed, there is no way we can get it back. Female leaders at all levels and sectors save their and others' time by focusing on resolving each job. They should not overestimate their abilities and take too many responsibilities, which may lead to uneffective working and unable to finish works. Ho Chi Minh explained: "It has to be focused. Having many goals is disoriented. Do not shoot any target" (Central Committee of the Communist Party of Vietnam, 2011). 
The scientific working style requires female leaders at all levels and sectors to work on objective data, based on the actual foundation to choose the most feasible plan and the plan must be put in overall long-term strategy. Do not fall into the trap of "Near-sighted disease - unable to look far. People having this disease cannot see the important things but only focus on small details" (Central Committee of the Communist Party of Vietnam, 2011). We cannot let the small benefits harm the great and long-term benefits. Vision is the quality of female leaders at all levels and sectors with scientific thinking and ways to work scientifically.

According to Ho Chi Minh, the scientific working style requires officials to have a way of judging the right person, the right job, and arranging the job properly. They must know how to check, supervise the work and other staff effectively, through that they must see the implementation of the Party's guidelines and resolutions and what needs to be adjusted. He said: "The objective situation changes for hours and minutes; a policy can be true for today but tomorrow it may not suit the situation anymore. If we do not consciously review our behavioral ideas to remove the unsuitable and the wrong, we will definitely not keep up with the situation" (Central Committee of the Communist Party of Vietnam, 2011) and "Testing allows us to mobilize the positive spirit and tremendous force of the mass, know clearly the capacity and shortcomings of officials for repairing and timely supports" (Central Committee of the Communist Party of Vietnam, 2011). If female leaders at all levels and sectors work in a tight and scientific manner, their staff cannot overlook them. And after each work we have to get the experience. Ho Chi Minh wrote: "For every work that succeeds or fails, we need to study the roots, separate it clearly and conclude. That conclusion will be a key to develop work and to help officials move forward" (Central Committee of the Communist Party of Vietnam, 2011).

\subsubsection{Making model style}

According to Ho Chi Minh, every official and party member must set a model in every work, from small to big, in all aspects. They have to be hardworking, honest, righteous, speak and work at the same time, "try to set a model for colleagues. When going out, we must set a model for others" (Central Committee of the Communist Party of Vietnam, 2011).

He reminds officials and party members: "In front of the mass, writing 'communist' on our forehead doesn't make people love us. The mass only adores people who are good moral characters. In order to guide people, I have to make a plan for people to imitate" (Central Committee of the Communist Party of Vietnam, 2011). You must be right to help others. If you are not right but still ask others to be right, it is unreasonable.

Female leaders at all levels and sectors should set models on the relationship with themselves, with people, and with their job. In the relationship with themselves, they should not be egotistical, overproud, arrogant, to always learn to progress, self-criticize to develop good things, modify bad things. They also need to self-criticize everyday. In the relationship with others, we have to always keep sincere, humble, united, honest attitude, not deceitful, be tolerant and generous. For the job, no matter what circumstance, it is necessary to keep the principle of "the supreme merit", put the work upwards, before the private issues.

Making model must go along with working. Speaking and working must go with each other. It is not only a standard in traditional morality but also a minimum standard of ethical service. Female leaders at all levels and sectors need to have a close agreement between speaking and doing, between morality and moral model, need to be consistent in work and personal life, in leadership ethics and everyday morality. The higher the status, the greater the prestige, the more effort must be made to improve morality and unity between speaking and doing. Each official, party member, female leader at all levels and sectors needs to be a model in their work and lifestyle, at all times and in every place so others can follow.

Speaking goes hand in hand with doing will give people the trust and respect for female leaders at all levels and sectors. This makes it easy for them to enforce their leadership. Ho Chi Minh also criticized some officials for "Only speaking and speaking, speaking hour after hour, day after day but cannot do something for real" (Central Committee of the Communist Party of Vietnam, 2011). In order to practice speaking and doing, female leaders at all levels and sectors must regularly review and scrutinize themselves, encourage staff and the public to comment, criticize, and remind them for what they promised. Female leaders at all levels and sectors must also know to avoid running after achievements. 
In agencies, organizations, female leaders at all levels, sectors must be models for their staff. In daily life, they must be responsible for good self-cultivation to become people with a clear life, as models for others to follow.

Among the models, female leaders at all levels and sectors must always set a model of the serving people spirit. President Ho Chi Minh stressed the responsibility of serving people from a philosophy: "People make rice for us to eat, clothes for us to wear so we have to pay them equally". Therefore, female leaders at all levels and sectors must be aggressive, enthusiastic, close to the people, exemplary and dare to take responsibilities with citizens by words and works.

In order to educate by setting a good model, female leaders at all levels and sectors should keep in mind the policy of President Ho Chi Minh: "Making model of good people, good deeds for daily education is one of the best ways to build the Party, revolutionary organizations, new people, and new life" (Central Committee of the Communist Party of Vietnam, 2011). He affirmed: "Good people, good things are everywhere, at every age" (Central Committee of the Communist Party of Vietnam, 2011). In June 1968, he directed to publish the book "Good people, good works" for everyone to study, follow, spread goodness and beauty in the society.

\subsubsection{Applying Ho Chi Minh' leadership style in training officials and female leaders at all levels and sectors}

\subsubsection{Democratic, but assertive style}

President Ho Chi Minh asked leaders to "gather all individual opinions of people, then analyze, study them, set them into systematic opinions". Leaders then them to propaganda, explain to the mass, make it the opinion of the mass, and make the public maintain and practice that idea. At the same time, when the mass practices, leaders have to reconsider whether it is right or not, then focus on public opinion, develop the advantages, fix the shortcomings, propagate, explain, make the public maintain and practice.

Keep doing that, the next time we will get more accurate, energetic, and fuller than the last time. That is a very good way of leadership (Central Committee of the Communist Party of Vietnam, 2011).

In the work, female leaders at all levels and sectors need to practice how to link leadership to the mass and to link policies with their own direction, to apply common views and procedures to each specific circumstance. According to President Ho Chi Minh, it is the leadership and management.

Democratic leadership style is based on the mass. Female leaders at all levels and sectors must not be bureaucratic and arrogant, disregarding the mass. They must know how people's real life, what people are real abilities. What they are thinking and looking forward to. Each word and action of female leaders must be suitable for the mass, reflecting the aspirations of the people, knowing their concerns to timely fix and solved.

President Ho Chi Minh criticized the leadership of some non-democratic officials, leading to the situation that people who have opinions do not dare to say, those who want to criticize do not dare to criticize, causing separations between leaders and others. Because of this, people stay distance with Party, do not have creativity, and are not eager to work. He pointed out: "If the leader wants to know his strengths and weaknesses, whether his work is good or bad, he can simply ask his staff to boldly propose ideas and criticisms. This is to not violate the prestige of the leader, but also shows honest democracy in the Party".

If staff does not speak, do not leave opinions, do not criticize but being flatter, it is a very bad phenomenon. It is not that they don't have anything to say, but because they do not dare to speak, and are afraid. This will lead to a loss of democracy in the Party. In this case, the Party's atmosphere will be dum; officials became machines, get frustrated, do not dare to speak, and finally have the resentful and depressed feelings" (Central Committee of the Communist Party of Vietnam, 2011).

Female leaders at all levels and sectors must have a truly democratic working style, not just show off to hide personal bad intentions. Because all artificial things will weaken, even break the community, all forms of socialism will soon erode, even democracy will be eliminate. Leaders have a responsibility in a community and have to practice democracy while listening to the mass's opinions. On the other hand, they have to be assertive, fully aware of their responsibilities and dare to make decisions, to do, to take responsibilities. This is also the strict implementation of the principle of "the mass leads, individuals are in charge" (Central Committee of the Communist Party of Vietnam, 2011).

According to Ho Chi Minh, no matter how talented a person is, it is impossible to grasp every aspect of a problem, know everything in the unit as well as social life. Female leaders at all levels and sectors need to work collectively 
to promote the collective intelligence and the mass. It is democratic when the mass leads. And in order to raise responsibilities of female leaders we have to put individuals in charge. If they have a high collective consciousness, creating a democratic working atmosphere, respecting and listening to collective opinions, promoting collective intelligence, but not being assertive, not dare to take personal responsibility, it is impossible to make timely decisions, meet the requirements and the work cannot be done. President Ho Chi Minh asked the leaders and managers that: "For normal things, if one person can handle properly, then the person can take care of it carefully. For important things, it needs collective decision" (Central Committee of the Communist Party of Vietnam, 2011).

According to Ho Chi Minh, the responsibility of leaders must be emphasized, sometimes it plays a decisive role to the efficiency of work. The working style of female leaders must be the unify of democratic and collective style with assertiveness, dare to take personal responsibility before the mass, promptly make correct decisions. In decisive moments, female leaders must dare to think, dare to do, dare to decide, which is directly related to taking advantage of opportunities.

\subsubsection{Close leadership style}

In practice, Ho Chi Minh is a shining model of a close leadership style. According to statistics of the Ho Chi Minh Museum, only in 10 years of building socialism in the North (1955-1965), even though he was old and busy with work, he made more than 700 visits to localities, construction sites, enterprises, cooperatives, army units etc., from mountainous areas to islands, to visit soldiers and compatriots, to review the situation and inspect jobs. Each year, he had more than 60 visits to localities, about 6 times a month he went to meet people. In addition, he read newspapers letters people sent to him daily. If he saw good ideas, urgent works to be solved, he would use red pens to mark them and transfer to other agencies for solutions.

Female leaders at all levels and sectors with the close leadership style can enhance their objectivity and transparency; strengthen the inspection and supervision capacities. From that, they can better control the enforcement of power, inspection and closely monitor professionals and professional activities of the industry and units.

According to Ho Chi Minh, the resolution that was issued must organize well the implementation so it can come to life. That is associated with inspection and supervision. If they want good works, they "must go to the place, see the people" (Central Committee of the Communist Party of Vietnam, 2011). People think that the reason why truth is still covered is because the inspection and supervision are not serious and not strict.

After checking and supervising, the wrong things need to be repaired right away. The good ones must be encouraged and rewarded, promptly to educate and motivate others. President Ho Chi Minh demanded to quickly praise the examples of good people, good deeds, to give material and spiritual encouragement, to develop good, against bad, for the purpose of training new people, making society more and more progressive. When reading newspapers, seeing examples of "good people, good deeds", especially those who are at the forefront of initiating the movement, Ho Chi Minh always sent to his staff to verify and give "Uncle Ho's Badge" to the people. There were about 5,000 people in the whole country who have been awarded "Uncle Ho's Badge" by the President Ho Chi Minh through the movement of "Good people, good deeds". Those who receive "Uncle Ho Badge" are proud to retell the touching stories when receiving this noble reward. Those rewards, later on, will become an example for their descendants.

\subsubsection{Smart use of talents and pay respect to them}

If female leaders at all levels want to be good leaders, they need to learn from President Ho Chi Minh in using people and using talents. Starting from the common goal of national independence and utility, President Ho Chi Minh gathered well-trained intellectuals from Western countries and officials of the feudal court to support the revolution.

President Ho Chi Minh determined that using people must be reasonable, base on their capabilities, use the right people for the right jobs, do not "use a carpenter as a blacksmith" (Central Committee of the Communist Party of Vietnam, 2011). Leaders have to let them understand everything of the works they are responsible for. Ho Chi Minh said "our leadership is still poor, the bureaucracy is still strong, so these people are normally underestimated and underpointed. In order to avoid the loss of talent, we need to correct our leadership" (Central Committee of the Communist Party of Vietnam, 2011). Using wrong people, work will not be done, talented people will be upset. All these will be harmful for the Party and show weakness in the Party's workforce. President Ho Chi Minh requests leaders, managers to know how to use talents, otherwise they will "kill" talents. The use of talents from his point of view is continuous like "gardeners cultivate precious trees. Leaders must respect talents, respect officials, and each 
person who is useful for our common works" (Central Committee of the Communist Party of Vietnam, 2011). Using talents is to know who is suitable for which work: "Great talents are for big works; little talents are for small works. We put the right people to the right place. If we can use talents in that way, we will never have to worry about lack of talents" (Central Committee of the Communist Party of Vietnam, 2011). Right after the Democratic Republic of Vietnam established, while still facing difficulties, enemies in and out of the country, President Ho Chi Minh was interested in finding talented people to build the country and he was a good model for finding talents and respecting them. On November 14, 1945, on the National Salvation Newspaper, President Ho Chi Minh wrote: "It is necessary to have talents to build talents. We are lack of talents, but if we are clever in selecting, using and training, talents will grow". He always affirmed the importance to find people with both talent and morality (Central Committee of the Communist Party of Vietnam, 2011).

President Ho Chi Minh said that does not know how to use talents is a big flaw, a waste of precious capital of the Party and the State in constructing and developing the country.

\subsubsection{Revolutionary, scientific, dynamic, creative style}

An important requirement in the style of female leaders at all levels and sectors is to have consistency between party characteristic and commitment with principles while having flexibility, creativity, sensitivity to new things. "Loyal to the Party, to the country, to the people" (Central Committee of the Communist Party of Vietnam, 2011) is the fundamental political quality, reflected in all activities of female leaders at all levels and sectors.

President Ho Chi Minh affirmed that the key thing in the working style of leading officials is: "Working hard for the Party, maintaining the Party's disciplines, well implementing the Party's policies and guidelines. Leaders must put the interests of the Party and people above individual interests; whole heartedly serve the people. Everything they do is for the Party, for the people, and they have to always make model for others" (Central Committee of the Communist Party of Vietnam, 2011).

Revolutionary enthusiasm is the basic factor in the quality of female leaders at all levels and sectors. Because of the revolutionary enthusiasm, female leaders are passionate and dedicated to work, find creative plans to implement their tasks effectively. Patriotism, revolutionary spirit and care for people are great motivations for female leaders at all levels to be dedicated and passionate about work. Female leaders at all levels and sectors need to have creative research and propose good ideas and optimal plans to perform their tasks. They have to be both professional and talented with revolutionary morality, a heroic and exemplary spirit, endure hardship, sacrifice and have the ability to perform well their assigned tasks.

Ho Chi Minh said that scientific style must be ensured by scientific knowledge. Revolutionary enthusiasm only works when it is unified with scientific knowledge and on a scientific basis. Revolutionary enthusiasm will become idealistic, single-minded without scientific knowledge. The reality shows that enthusiasm and lack of scientific knowledge will lead to mistakes, deflections, disruptions to policies, illegal acts, and even unconscious destruction. Programs, projects, plans having good ideas, but lack of knowledge will fail and cause heavy losses.

In order to have scientific knowledge, female leaders at all levels and sectors have to study hard to improve their political, cultural and professional qualifications as well as to understand the situation at in and out of the country. If they are subjective, complacent, do little theoretical and practical research, it is easy for them to be optimistic; getting early success easily makes them arrogant; facing difficulties makes them confused, passive, which leads to pessimism, fluctuations, unstable revolutionary stance etc. President Ho Chi Minh reminds officials in general, especially leaders: "Learning is a continuous process we have to do for a lifetime. For our life, we have link theory and practical work. Nobody can claim to know everything and the world is changing day by day. Besides, people are getting better and better, so we must continue to study and practise to keep up with them" (Central Committee of the Communist Party of Vietnam, 2011).

One of the requirements on the working style of female leaders at all levels and sectors is to firmly grasp the theory but to also have the abilities to apply that theory into practice. Ho Chi Minh pointed out: "Learning Marxism - Leninism is learning the spirit of managing everything, for everyone and for myself; is learning the common truths of Marxism - Leninism to creatively apply to practical situations in our country" (Central Committee of the Communist Party of Vietnam, 2011). All resolutions and policies of the Party must come from the specific situation on the one hand, explain to the public so that they can understand and implement those policies and resolutions. This is to assure theory to go in line with practise. 
In all activities, depending on specific circumstances, female leaders at all levels and sectors can use many forms and measures to fulfill their responsibilities and tasks. Along with the loyal to keep principles, on strategic issues and revolutionary strategies, the forms, methods, measures and methods of implementation must be flexible, suitable to reality to get the highest results. That depends on the leader's capacities to stay calm dealing with any situation (Central Committee of the Communist Party of Vietnam, 2011) and is shown in the flexibility of each individual.

According to Ho Chi Minh, the immutability, the goal in all revolutionary periods is independence, unification for the country, freedom and happiness for the people. In his will, he spoke out his final wish which is also the common goal of the revolution, "to build a peaceful, united, independent, democratic and wealthy Vietnam" (Central Committee of the Communist Party of Vietnam, 2011). The path to that goal is a long, difficult and arduous struggle. Leaders need to be smart, alert, sensitive to determine strategies, forms, measures to be taken in specific circumstances and conditions, in each and every step forward of revolution. The content of building leadership style, towards the common goals is not beyond the regulations and work requirements for leaders.

In the current integration period, female leaders at all levels and sectors also need to be charming and soft, comply with 10 common leadership principles of the modern society:

(1) Lead with integrity and honesty;

(2) Respect others;

(3) Show courage;

(4) Be willing to accept risks and changes;

(5) Not to be a perfectionist;

(6) Stay focused;

(7) Be sensitive;

(8) Share and find information;

(9) Be confident;

(10) Seize conflict, do not avoid conflict.

At the same time, they need to convey motivation and inspiration to help the mass and employees to maximize their personal capacities. Different approaches need to be taken to solve the problem flexibly to encourage the interaction of people in a diverse environment.

From analyzing President Ho Chi Minh's working style to making recommendations on the qualities that female leaders should have, the article proposes a number of solutions to build and develop female leaders who meet the requirements of Ho Chi Minh's working style, the requirements of Vietnamese society in global integration, and other tasks of a democratic, modern, dynamic and professional administrative system to effectively serve people, innovating and creative activities.

- To continue to raise awareness, viewpoints and responsibilities of the political and managing system at all levels and sectors on gender equality and female officials.

- To enhance the work of planning, training, fostering and employing female leaders at all levels and sectors; to regularly review, nurture and appoint female leaders.

- To include gender equality in planning, training, fostering and employing female officials in leading and managing position at all levels and sectors; to take specific measures to provide training, professional training, and political theories for female leaders; to ensure the percentage of female leaders in each working term.

- To promote the spirit of self-study, training and self-improvement in female officials and leaders at all levels and sectors.

- To coordinate well the activities of the Party Committees and Women's Unions at all levels with other social organizations to advise, propose, develop and implement policies on female officials and leaders in order to have a sources of quality female leaders at all levels and sectors.

\section{DISCUSSION AND CONCLUSION}

In short, building the working style for female leaders at all levels and sectors in Vietnam following the model of Ho Chi Minh in a creative way, in line with today's social reality, is an important task of the industry, training high quality human resources, and female leaders at all levels. This work helps female officials and leaders at all levels and sectors to be more clean, strong, virtuous, talented, capable of professional skills, active living capacity... They are leaders and officials that adapt and meet the demands of the renovation, exchange, integration, sustainable development of the country. 
Female leaders at all levels and sectors in Vietnam are now learning Ho Chi Minh's working style creatively as well as practising and establishing working style and leadership which are democratic, scientific, suitable for public and taking the role model. It is the creation and implementation of the country's sustainable development plan that brings practical benefits to the nation now and in the future. In the process of sustainable development, female leaders at all levels and sectors in Vietnam who have practised and learned a democratic, assertive, profound, scientific, revolutionary, active, creative leadership style of President Ho Chi Minh will soon have the virtue, talent, competence to meet the innovation and global integration in the sustainable development of Vietnam. They are the ones who understand more than anyone else the role, spillover effects, positive influence of female leaders in current and future society. They will be the creators and contribute significantly to change the perception on female leaders' role and contribution when they participate in leadership and management. Specifically, they will raise senior officials' awareness, emphasize the importance and effectiveness of the equal share between men and women in decision making positions. They will also raise men's awareness on taking more housework to support female leaders in pursuing careers and getting career successes; raise community's awareness on the important position of female leaders in our society; create pressure to change gender perceptions of people in leading and senior management positions; make changes in human resource, communication and administration policies - issues that help promote equality, create favorable conditions and opportunities for female leaders to participate, develop capacity, intelligence and contribute to sustainable development of organizations and society. The development of policies to raise people's awareness, especially to bring necessary knowledge and information on laws to women, so that they can become a great force entering the society to support elite female figures to undertake common task for the country.

\section{REFERENCES}

Central Committee of the Communist Party of Vietnam (2011). Ho Chi Minh: A Biography ( $3^{\text {rd }}$ edition). CD-ROM.

Diep, D. X. (2012). Women's role in provincial agencies in Ca Mau province. Project empowerment of women in the public sector in the context of international economic integration (EOWP). Ministry of Foreign Affairs of Vietnam and UNDP.

Government (2009). Government's Action Plan to 2020 implementing Resolution No. 11-NQ/TW dated April 27, 2007 by the Politburo on women's works in increasing industrialization and modernization of the country. Retrieved from http://www.chinhphu.vn/portal/page/portal/chinhphu/hethongvanban?class_id=509\&mode $=$ detail\&document_id=91916

Gwen K. Young (2016). Why we need more women leaders. Retrieved from https://edition.cnn.com/2016/07/29/ opinions/women-rising-benefits-society-young/index.html

Hanh, C. T. (2012). Current situation and some solutions enhancing women's involvement in leadership and making decision at all levels in Nam Dinh province. Project Empowerment Of Women In The Public Sector In The Context Of International Economic Integration (EOWP). Ministry of Foreign Affairs of Vietnam and UNDP.

Hien, L. T. (2018). The importance of female leader from the perspective of modern theories. Center for Gender and Female Leader Research, Ho Chi Minh National Academy of Politics.

Muro, Jean (2012). Women's Participation in Leadership and Management in Vietnam. Report.

Nana Kalandadze (2015). Women in politics - achieving key milestones. Retrieved from https://www.idea.int/ news-media/news/women-politics-\%E2\%80\%93-achieving-key-milestones\%C2\%A0

Pilar Tello Rozas (2017). Has progress been made in the promotion of women's political participation in Peru?. Retrieved from https://www.idea.int/news-media/news/has-progress-been-made-promotion-women\%E2\%80\%99spolitical-participation-peru

The Prime Minister (2010). Decision No. 2351/QD-TTg dated December 24, 2010 Approving the 2011-2020 national strategy for gender equality. Retrieved from https://thuvienphapluat.vn/van-ban/Van-hoa-Xa-hoi/Quyetdinh-2351-QD-TTg-phe-duyet-Chien-luoc-quoc-gia-binh-dang-gioi-116501.aspx

Thi, T. T. M. (2016). Institutional and cultural barriers for women's involvement in politics in Vietnam. Journal on Family and Gender, 3, 46-59.

William Sjöstedt (2018). Gender-targeted public funding to support women in politics: the Albanian case. Retrieved from https://www.idea.int/news-media/news/gender-targeted-public-funding-support-women-politics-albanian-case. 